\title{
Groundwater quality and its suitability for drinking and irrigational use in the Southern Tiruchirappalli district, Tamil Nadu, India
}

\author{
S. Selvakumar $\cdot$ K. Ramkumar $\cdot$ N. Chandrasekar $\cdot$ \\ N. S. Magesh $\cdot$ S. Kaliraj
}

Received: 31 May 2014/ Accepted: 16 November 2014/Published online: 10 December 2014

(C) The Author(s) 2014. This article is published with open access at Springerlink.com

\begin{abstract}
A total of 20 groundwater samples were collected from both dug and bore wells of southern Tiruchirappalli district and analyzed for various hydrogeochemical parameters. The analyzed physicochemical parameters such as $\mathrm{pH}$, electrical conductivity, total dissolved solids, calcium, magnesium, sodium, potassium, bicarbonate, carbonate, sulfate, chloride, nitrate, and fluoride are used to characterize the groundwater quality and its suitability for drinking and irrigational uses. The results of the chemical analysis indicates that the groundwater in the study area is slightly alkaline and mainly contains $\mathrm{Na}^{+}, \mathrm{Ca}^{2+}$, and $\mathrm{Mg}^{2+}$ cations as well as $\mathrm{HCO}_{3}{ }^{2-}, \mathrm{Cl}^{-}, \mathrm{SO}_{4}{ }^{2-}$ and $\mathrm{NO}_{3}{ }^{-}$anions. The total dissolved solids mainly depend on the concentration of major ions such as $\mathrm{Ca}, \mathrm{Mg}, \mathrm{Na}, \mathrm{K}, \mathrm{HCO}_{3}, \mathrm{Cl}$, and $\mathrm{SO}_{4}$. Based on TDS, $55 \%$ of the samples are suitable for drinking and rest of the samples are unsuitable for drinking. The total hardness indicates that majority of the groundwater samples are found within the permissible limit of WHO. The dominant hydrochemical facies for
\end{abstract}

\footnotetext{
S. Selvakumar $(\bowtie) \cdot$ N. Chandrasekar .

N. S. Magesh · S. Kaliraj

Centre for Geotechnology, Manonmaniam Sundaranar

University, Tirunelveli 627 012, India

e-mail: geoselvas@gmail.com

N. Chandrasekar

e-mail: profechandra@gmail.com

N. S. Magesh

e-mail: mageshissivan@gmail.com

S. Kaliraj

e-mail: thayakaliraj@gmail.com

K. Ramkumar

Department of Civil Engineering, Roever college of Engineering and Technology, Perambalur 621 212, India

e-mail: rcetram@yahoo.in
}

groundwater are $\mathrm{Ca}-\mathrm{Mg}-\mathrm{Cl}, \mathrm{Ca}-\mathrm{HCO}_{3}$, and $\mathrm{Ca}-\mathrm{Cl}$ type. The USSL graphical geochemical representation of groundwater quality suggests that majority of the water samples belongs to high medium salinity with low alkali hazards. The Gibb's plot indicates that the groundwater chemistry of the study area is mainly controlled by evaporation and rock-water interaction. Spearman's correlation and factor analysis were used to distinguish the statistical relation between different ions and contamination source in the study area.

Keywords Groundwater hydrochemistry · Quality assessment $\cdot$ Correlation analysis $\cdot$ Factor analysis - India

\section{Introduction}

Groundwater has become the most important source of water used for domestic, industrial, and agricultural sectors of many countries. In India, most of the population (85\%) resides in rural areas and they depend mostly on groundwater resources for their daily needs. In which, approximately $50-80 \%$ of the irrigated land is under groundwater consumption (Raju 1998). The rapid industrialization and expansion of cities impose a high pressure on water resources including groundwater which often results in their depletion and contamination. The quality of groundwater depends on various chemical constituents and their concentration is mostly derived from the geological data of the particular region. Generally, the quality of groundwater depends on the composition of recharge water, the interaction between the water and the soil, the soil-gas interaction, the rock with which it comes into contact in the unsaturated zone, the residence time, and reactions that take place within the aquifer (Freeze and Cherry 1979; 
Hem 1989). Groundwater quality in a region is largely determined by both natural processes (dissolution and precipitation of minerals, groundwater velocity, quality of recharge water, and interaction with other types of water aquifer) and anthropogenic activities (Andrade et al. 2008). The natural chemical quality of groundwater is generally good, but elevated concentrations of a number of constituents can cause problems for water use. The geochemistry of groundwater data gives crucial evidence to the geologic history of rocks and indications of groundwater recharge, movement, and storage (Walton 1970).

The natural chemical quality of groundwater depends on geological as well as geographical arrangement in the region (Chandrasekar et al. 2013). Hydrochemical evaluations of groundwater flow systems are generally based on the availability of information on groundwater chemistry (Shuxian 2013). The intensive use of natural resources and production of wastes in modern society often cause a threat to groundwater quality that have resulted in many incidents of groundwater contamination. Such contamination can be statistically interpreted and it is very useful due to its relative importance in evaluating the combination of large chemical variable dataset. In the last decades, methods such as hierarchical cluster analysis (HCA), discriminant analysis (DA), correlation analysis, and principal component analysis (PCA) have become accepted in identifying variations and sources of groundwater pollution (Zhang et al. 2012; Gordana et al. 2014). Principal component analysis (PCA) and Spearman's correlation matrix have been frequently applied to analyze the pollution parameters in groundwater (Selvakumar et al. 2014). The PCA analysis is an effective tool in exploratory data analysis to probe with the spatial controlling processes (Subba Rao. 2014). In fact, industrial waste and other municipal solid waste have emerged as one of the leading cause of pollution of surface and groundwater. Human-induced activities can modify the natural source of contaminants and also initiate pollution load in the receiving water bodies (Whittemore et al. 1989). The surface as well as groundwater quality induces environmental degradation over long period of time because of discharge of highly contaminated effluent accelerated by overexploitation of existing water resources (Carneiro et al. 2010). During infiltration, recharged water interacts with soils, weathered materials, and fractured rocks and carries pollutants released from the land use activities; these pollutants are dissolved depending upon their solubility in the water, before reaching the groundwater body (Subba Rao 2014). The deterioration of groundwater quality affects its usage for drinking, agriculture, and industrial activities (Brindha and Elango 2012). About $80 \%$ of the diseases in the world and one-third of the deaths in the developing countries are caused by the drinking of contaminated water (WHO 2004).
In developing countries like India, around $80 \%$ of all diseases are directly related to poor drinking water quality and polluted conditions (Olajire and Imeokparia 2001). The principals governing the chemical characteristics of groundwater were well documented in many parts of the world. In order to understand the pollution trends and impacts on aquifers, it is essential to have knowledge of the natural baseline quality so that imposed environmental change can be measured with an acceptable degree of confidence (Edmunds et al. 2003).

Various researchers (Muthukumar et al. 2011; Jameel et al. 2004) have characterized the geochemistry of groundwater in Tiruchirapalli district. However, a detailed geochemical and groundwater quality study on the Thiruverambur and Thuvakudi taluks has not been reported so far. So it is essential to have an idea about the quality of the existing water resource, which will aid in the rapacious usage in future. Such study will highlight the nature of groundwater with respect to natural and other anthropogenic effects.

The aim of the present study is to assess the hydrochemistry and groundwater quality for drinking and irrigation usage from Thiruverambur to Thuvakudi taluks located in Trichirappalli District, Tamil Nadu, where the groundwater is a prime source for drinking and irrigation due to non-availability of surface water supply in time.

\section{Study area}

Tiruchirappalli is situated on the banks of the river Cauvery and it is centrally located in Tamilnadu with an area of $11,098 \mathrm{~km}^{2}$. The area chosen for the present study (Thiruverambur and Thuvakudi taluks) is located in the southern part of the Tiruchirappalli district with the geographic coordinates of $10^{\circ} 75^{\prime}-10^{\circ} 78^{\prime} \mathrm{N}$ and $78^{\circ} 77^{\prime}-78^{\circ} 83^{\prime} \mathrm{E}$. The northeastern part of the Tiruchirapalli district is occupied by alluvium of the river Cauvery while the residual hills are seen in the northeastern part of the city. The location map of the study area map is presented in Fig. 1. The area receives rainfall mostly from the northeast monsoon with an average of about $880.52 \mathrm{~mm}$ (CGWB 2008). The major soil types in the district are black cotton soils, red sandy to loamy soils, and alluvial soils. A thin layer of red sandy soils overlies the western and southern parts of the district. The study area is geologically composed of granite gneisses and charnockites of archean and precambrian age with weathered nature of the terrain. Groundwater generally occurs under phreatic conditions in the weathered mantle and under semi-confined conditions in the fissure and fracture zones at deeper levels. The depth of water level during pre-monsoon and post-monsoon varied from 2 to $10 \mathrm{~m}$ and 1.5 to $15.5 \mathrm{~m}$ below ground level, respectively. 


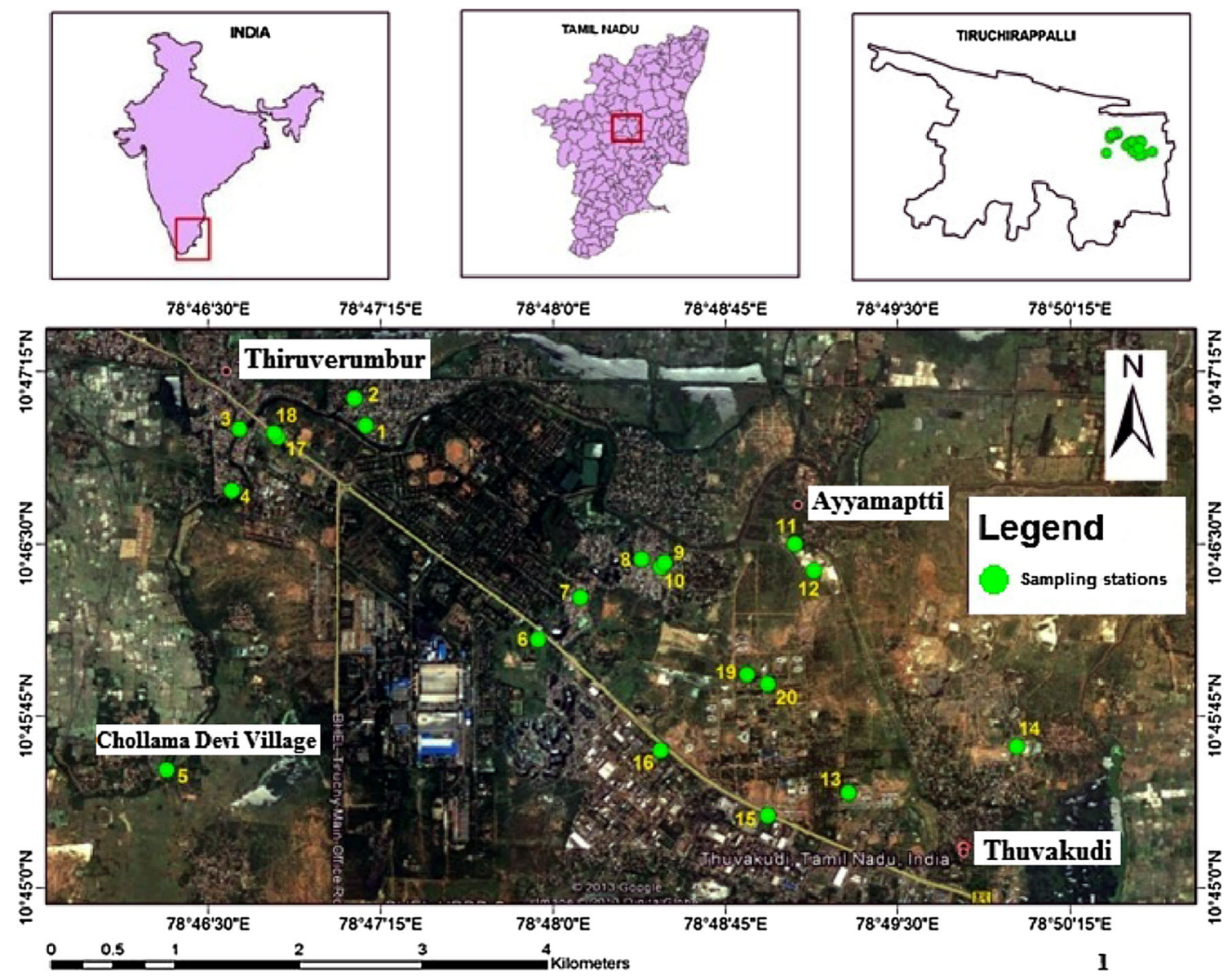

Fig. 1 Location map of the study area

The yield of the wells at the time of drilling and development ranged from less than 1-20 lps. The transmissivity (T) of the wells varied from 32 to $782 \mathrm{~m}^{2} /$ day. Hydraulic conductivity varied from 2 to $66 \mathrm{~m} /$ day and storativity of the aquifer in the range of $1.6 \times 10^{-4}-9.6 \times 10^{-4}$. The thickness of weathered zone in the district ranges from 2 to $25 \mathrm{~m}$. Most of the area is under cultivation, especially for raising dry crops and limited paddy cultivation. The source of irrigation and their distribution is very much limited due to unavailability of water resources.

\section{Materials and methods}

A total of 20 groundwater samples have been collected from dug and bore wells during March 2013 and analyzed to understand the physicochemical variations of water quality parameters using standard methods (APHA 1995). Samples were collected in one liter capacity high density polyethylene (HDPE) bottles. Prior to collection, the bottles were thoroughly washed with dilute $\mathrm{HNO}_{3}$ acid, and then with distilled water in the laboratory before sample filling. Each bottle was rinsed to avoid any possible contamination in bottling and every other precautionary measure was taken. Each groundwater sample was analyzed for $\mathrm{pH}$, electrical conductivity (EC), major cations and anions. The $\mathrm{pH}$, electrical conductivity (EC), and total dissolved solids (TDS) were measured in situ using HANNA portable water quality meter (HI-9828, USA). The total hardness $(\mathrm{TH})$ and calcium were estimated by titrimetric method using EDTA and magnesium concentration was estimated by the difference in the hardness and calcium. Total alkalinity, bicarbonate, and chloride were estimated by titrimetric methods. The concentrations of sodium and potassium were estimated by flame photometer (DEEP VISION, Model-381). The sulfate and nitrate ions were analyzed by the UV-Visible Spectrophotometer. Fluoride was estimated by using an ion-selective electrode (ISE) with a $\mathrm{pH} / \mathrm{ISE}$ meter. Statistical analysis such as correlation matrix and factor analysis was performed using the IBM SPSS Statistics. Major hydrochemical facies were identified through Piper trilinear diagram (Piper 1944) using Aquachem Scientific v4.0 software. US Salinity diagram was carried out to recognize the various hydrogeochemical types in the groundwater and its suitability for irrigation purposes. 


\section{Results and discussion}

The descriptive statistics of the physicochemical parameters of the analytical data and the permissible limits of various organizations such as World Health Organization (WHO), Indian Standard Institution (ISI), and Bureau of Indian Standards (BIS) are presented in Table 1.

Suitability of groundwater

\section{Drinking water}

The $\mathrm{pH}$ in the study area ranges from 6.83 to 8.04 with an average value of 7.41. This shows that the groundwater in the study area is slightly alkaline in nature and found within the maximum permissible limits of WHO standards. The EC values range from 542 to $3,606 \mu \mathrm{S} / \mathrm{cm}$ with an average value of $1,534 \mu \mathrm{S} / \mathrm{cm}$. The TDS values vary between 347 to $2,308 \mathrm{mg} / \mathrm{l}$ with an average value of $983 \mathrm{mg} / \mathrm{l}$; for drinking purpose the maximum allowable TDS guideline value prescribed by the WHO (2004) is $1,000 \mathrm{mg} / \mathrm{l}$. The presence of TDS above this limit in groundwater would cause undesirable taste, gastrointestinal irritation. In the study area, nine samples $(1,5,6,7,8,9$, $10,12,18)$ possess TDS value above the WHO guideline value, which is not suitable for drinking purpose and other eleven samples $(2,3,4,11,13,14,15,16,17,19,20)$ are suitable for drinking. The high TDS value marked at station 12 , located in the agricultural land, may be due to the percolation of channel water containing fertilizers, solid, and agricultural wastes. The large variation in TDS is mainly attributed to anthropogenic activities and geochemical processes prevailing in the region. The total alkalinity value ranges from 222 to $594 \mathrm{mg} / \mathrm{l}$ with an average value of $379 \mathrm{mg} / \mathrm{l}$. According to Indian Standards (BIS 10500: 1991) all the water samples are under permissible limit $(600 \mathrm{mg} / \mathrm{l})$. Higher value of alkalinity in the study area is due to the concentration of leaching process through surface water during rainy season.

The concentration of calcium ranges from 30 to $205 \mathrm{mg} /$ 1 with an average value of $87.3 \mathrm{mg} / \mathrm{l}$ and magnesium ranges from 21 to $199 \mathrm{mg} / \mathrm{l}$ with an average value of $61.1 \mathrm{mg} / \mathrm{l}$. According to WHO (2004), almost all the water samples are within the permissible limit. Based on the total hardness all the water samples are found within the permissible limit $(500 \mathrm{mg} / \mathrm{l})$, except sample 12 which exceeded the permissible limit $(665.1 \mathrm{mg} / \mathrm{l})$ due to contamination of large quantities of sewage, detergents, and solid wastes.

The sodium ion concentration varies from 12 to $221 \mathrm{mg} / \mathrm{l}$ with an average value of $112.9 \mathrm{mg} / \mathrm{l}$. The sodium values exceed the desirable limit of WHO which is $200 \mathrm{mg} / \mathrm{l}$. All the groundwater samples except sample number 12 in the study area are within the permissible limit and are suitable for drinking. Sodium is found in association with high concentration of chloride resulting in salinity. Sodium concentrations are also influenced by the cation exchange mechanism. The potassium concentration varies between 9 and $90 \mathrm{mg} / \mathrm{l}$ with an average value of $40.1 \mathrm{mg} / \mathrm{l}$. High concentration of potassium is due to the effect of fertilizers and other industrial activities located near the site.

The bicarbonate values range from 93 to $298 \mathrm{mg} / \mathrm{l}$ with an average value of $192.2 \mathrm{mg} / \mathrm{l}$. The chloride concentration ranges from 26 to $1,010 \mathrm{mg} / \mathrm{l}$ and with an average value of $222.8 \mathrm{mg} / \mathrm{l}$. Chlorides are one of the major inorganic anions present in natural water. Chloride may be accumulated from agricultural activities, domestic sewage, and chloride-rich minerals or rocks. High concentration of chloride is considered to be the indicator of pollution by

Table 1 Drinking water standard specifications and statistical information of ionic concentrations

\begin{tabular}{|c|c|c|c|c|c|c|}
\hline Parameters (mg/l) & Minimum & Maximum & Mean & WHO 2004 & ISI 1983 & BIS 1991 \\
\hline $\mathrm{pH}$ & 6.83 & 8.04 & 7.41 & $6.5-8.5$ & $6.5-9.2$ & $6.5-8.5$ \\
\hline $\mathrm{EC}(\mu \mathrm{S} / \mathrm{cm})$ & 542 & 3,606 & $1,535.9$ & 1,500 & - & - \\
\hline TDS (mg/l) & 347 & 2,308 & 983.1 & 1,000 & 1,500 & 2,000 \\
\hline $\mathrm{Ca}(\mathrm{mg} / \mathrm{l})$ & 30 & 205 & 87.3 & 200 & 200 & 200 \\
\hline $\mathrm{Mg}(\mathrm{mg} / \mathrm{l})$ & 21 & 199 & 61.1 & 150 & 100 & 100 \\
\hline TH (mg/l) & 84.8 & 665.1 & 234.5 & 500 & 600 & 600 \\
\hline $\mathrm{Na}(\mathrm{mg} / \mathrm{l})$ & 12 & 221 & 112.9 & 200 & - & 150 \\
\hline $\mathrm{K}(\mathrm{mg} / \mathrm{l})$ & 9 & 90 & 40.1 & 12 & - & - \\
\hline $\mathrm{HCO}_{3}(\mathrm{mg} / \mathrm{l})$ & 93 & 298 & 192.2 & 500 & - & 400 \\
\hline $\mathrm{Cl}(\mathrm{mg} / \mathrm{l})$ & 26 & 1,010 & 222.8 & 600 & 1,000 & 1,000 \\
\hline $\mathrm{SO}_{4}(\mathrm{mg} / \mathrm{l})$ & 4 & 128 & 45.4 & 250 & 400 & 400 \\
\hline $\mathrm{NO}_{3}(\mathrm{mg} / \mathrm{l})$ & 1 & 26 & 10.9 & 45 & 45 & 45 \\
\hline $\mathrm{F}(\mathrm{mg} / \mathrm{l})$ & 0.2 & 0.9 & 0.65 & 1.5 & 1.5 & 1.5 \\
\hline
\end{tabular}

WHO World Health Organization, ISI Indian Standard Institution, BIS Bureau Indian Standards 
high organic wastes of animal or industrial origin. The chloride ion concentration in groundwater of the study area exceeds the permissible limit of $600 \mathrm{mg} / \mathrm{l}$ in one location.

The concentration of sulfate and nitrate ranges from 4 to $128 \mathrm{mg} / \mathrm{l}$ with an average value of $45.4 \mathrm{mg} / \mathrm{l}$, and 1 to $26 \mathrm{mg} / \mathrm{l}$ with a mean value of $10.9 \mathrm{mg} / \mathrm{l}$, respectively. These sulfate and nitrate concentration of the study area is within the permissible limit in all the sample locations. Fluoride is one of the main pollutants in groundwater, which generally occurs as a natural constituent. Bedrock containing fluoride minerals are generally responsible for high concentration of this ion in groundwater. The concentration of fluoride in groundwater varies from 0.2 to $0.9 \mathrm{mg} / \mathrm{l}$ with an average value of $0.65 \mathrm{mg} / \mathrm{l}$. The groundwater samples in the study area are found within the permissible limit of WHO $(1.5 \mathrm{mg} / \mathrm{l})$.

Groundwater quality classification

\section{Hydrochemical facies}

The geochemical evolution of groundwater can be understood by plotting the concentrations of major cations and anions in the Piper (1944) trilinear diagram. Aquachem Scientific software version 4.0 was used to construct this diagram. The geochemical evolution/hydrochemistry of groundwater in the study area was evaluated using the concentrations of major cations $\left(\mathrm{Ca}^{2+}, \mathrm{Mg}^{2+}, \mathrm{Na}^{+}\right.$and $\left.\mathrm{K}^{+}\right)$ and anions $\left(\mathrm{HCO}_{3}{ }^{-}, \mathrm{SO}_{4}{ }^{2-}\right.$, and $\left.\mathrm{Cl}^{-}\right)$in meq/l. This diagram reveals similarities and differences among water samples because those with similar qualities will tend to plot together as groups (Todd 2001). The plot shows that most of the groundwater samples $(70 \%)$ fall in the field of mixed $\mathrm{Ca}-\mathrm{Mg}-\mathrm{Cl}$ type of water, $25 \%$ of the samples fall in $\mathrm{Ca}-\mathrm{HCO}_{3}$ type, and remaining $5 \%$ of the sample fall in $\mathrm{Ca}-\mathrm{Cl}$ facies (Fig. 2). In the anions triangle, $60 \%$ of the samples fall in chloride type, $25 \%$ in bicarbonate type, and $15 \%$ in no dominant type. It reveals that $60 \%$ of the water samples are salty in nature.

\section{Mechanism controlling the groundwater chemistry}

Gibbs (1970) established the mechanism controlling the chemical composition of groundwater to find out a close relationship between chemical composition of water and aquifer lithological characteristics. In this diagram, three distinct fields are recognized such as evaporation dominance (rate of evaporation), rainfall dominance (chemistry of the precipitated water), and rock-water interaction on water chemistry. Gibbs plots were created from ratio I (for anion) $\mathrm{Cl} /\left(\mathrm{Cl}+\mathrm{HCO}_{3}\right)$ and ratio II (for cation) $\mathrm{Na} /(\mathrm{Na}+\mathrm{Ca})$ of the groundwater samples which are plotted separately against the respective values of TDS. Figure 3 indicates that most of the groundwater samples fall under evaporation dominance zone and few samples are placed under rock dominance zone. Evaporation process is not only a common phenomenon in surface water but also in groundwater system (Jankowski and Acworth 1997). The result reveals that evaporation is the dominant process due to dry and arid condition prevailing throughout the region. However, few samples fall under the rock dominance zone indicating the dissolution of silicate bearing rocks with groundwater.

\section{Correlation analysis}

'Correlation coefficient is a generally used evaluation to establish the relationship between two variables. Correlation between major ions was carried out by using Spearman's correlation matrix. Table 2 shows the correlation coefficients between the major ions in the study area. Based on the spearman's correlation, significant and high positive correlation $(r \geq 0.7)$ have been obtained for $\mathrm{Ca}^{2+}, \mathrm{Mg}^{2+}, \mathrm{Na}^{+}, \mathrm{K}^{+}$, and $\mathrm{Cl}^{-}$, and $\mathrm{SO}_{4}{ }^{2-}$ with TDS. The strong significant correlation of $\mathrm{Mg}^{2+}$ ion with $\mathrm{Cl}^{-}(r=0.900)$ and $\mathrm{Na}^{+}$with $\mathrm{NO}_{3}{ }^{-}$ $(r=0.913)$ reflects that the groundwater in the area has been contaminated due to application of excess amount of fertilizer, over exploitation, and anthropogenic activities. The variation of these relationships may indicate the complexity of the hydrochemical components of groundwater where natural water always contains dissolved and suspended substances of mineral origin (Elkrail and Obied 2012). The major source of $\mathrm{Mg}^{2+}$ and $\mathrm{Na}^{+}$in the groundwater was ion exchange of minerals between rocks and water. The $\mathrm{NO}_{3}^{-}$ion was strongly correlated with $\mathrm{Ca}^{2+}(r=0.743), \mathrm{Cl}^{-}(r=0.767)$, and $\mathrm{K}^{+}$ $(r=0.723)$, it indicates a possibility of contamination from fertilizers, municipal wastewaters, septic systems, and sometimes the cultivation of grasslands.

\section{Principal component analysis (PCA)}

Principal component analysis is a statistical method designed to analyze the interrelationships within a set of variables by reducing the complex information to an easily interpretable form. In this paper, the PCA was carried out using a set of data consisting of 20 groundwater samples to identify and characterize the factors that affect the hydrochemical composition of the study area. The PCA results comprising the loadings, eigen values, and percentages of total variance are summarized in Table 3 . The four factors explain $92.05 \%$ of the total variance in the dataset. The parameters with loadings whose absolute value is more than 0.65 are considered significant. Factor I, which explained $61.88 \%$ of the total variance, had strong positive loadings on $\mathrm{EC}, \mathrm{Ca}, \mathrm{Mg}, \mathrm{Na}, \mathrm{K}$, as well as $\mathrm{Cl}$ and $\mathrm{NO}_{3}$. The high loadings for the major ions such as $\mathrm{Ca}^{2+}, \mathrm{Mg}^{2+}, \mathrm{Na}^{+}$, and $\mathrm{Cl}^{-}$probably show the result of mineral-water

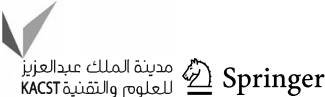


Fig. 2 Piper trilinear diagram showing hydrogeochemical facies of the groundwater
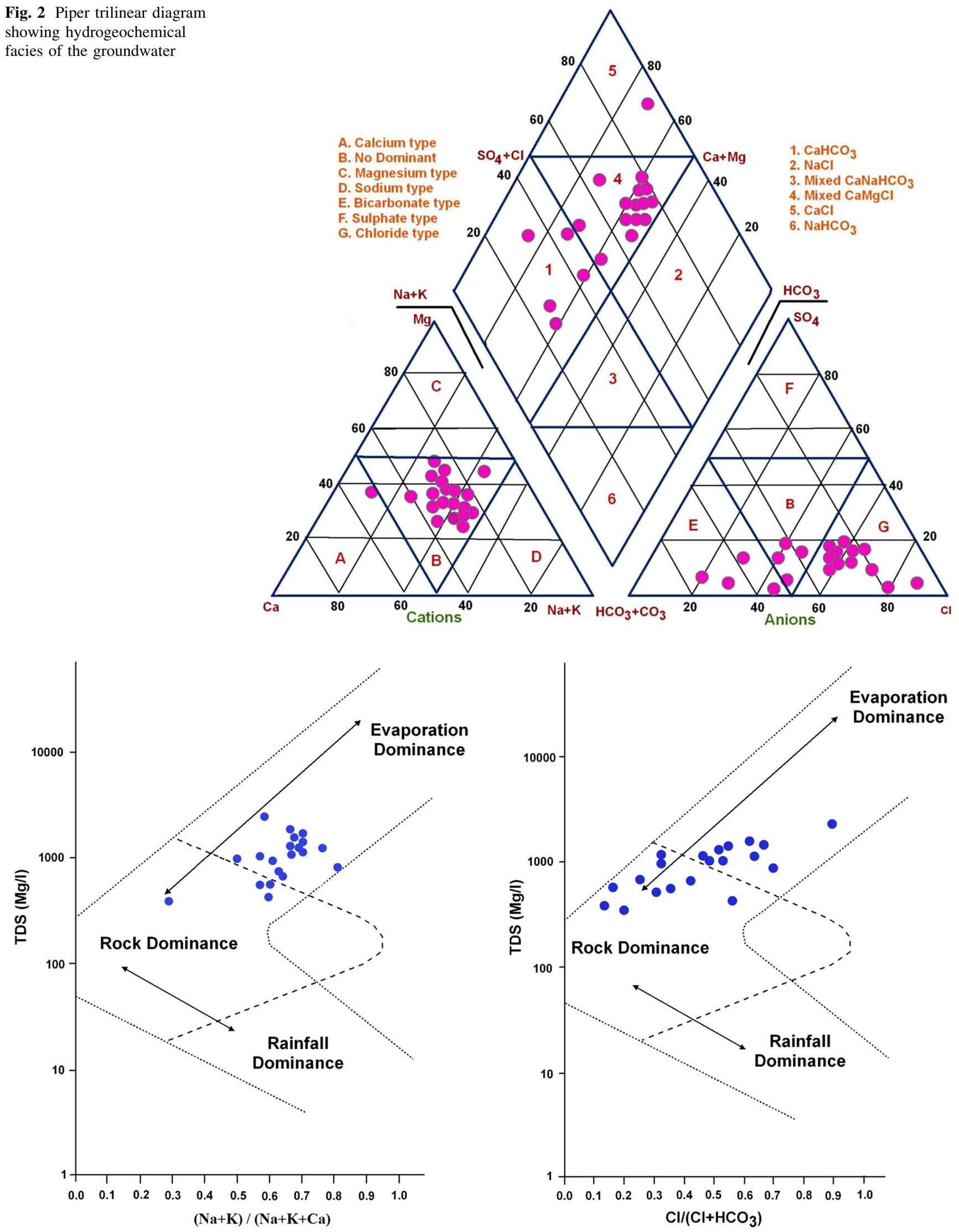

Fig. 3 Gibbs plot showing mechanism governing groundwater chemistry 
Table 2 Correlation matrix of physicochemical parameters of groundwater in the study area

\begin{tabular}{|c|c|c|c|c|c|c|c|c|c|c|c|}
\hline & $\mathrm{pH}$ & TDS & $\mathrm{Ca}^{2+}$ & $\mathrm{Mg}^{2+}$ & $\mathrm{Na}^{+}$ & $\mathrm{K}^{+}$ & $\mathrm{HCO}_{3}^{-}$ & $\mathrm{Cl}^{-}$ & $\mathrm{SO}_{4}{ }^{2-}$ & $\mathrm{NO}_{3}{ }^{-}$ & $\mathrm{F}^{-}$ \\
\hline $\mathrm{pH}$ & 1 & & & & & & & & & & \\
\hline TDS & -0.656 & 1 & & & & & & & & & \\
\hline $\mathrm{Ca}^{2+}$ & -0.514 & 0.917 & 1 & & & & & & & & \\
\hline $\mathrm{Mg}^{2+}$ & -0.491 & 0.861 & 0.830 & 1 & & & & & & & \\
\hline $\mathrm{Na}^{+}$ & -0.658 & 0.946 & 0.819 & 0.710 & 1 & & & & & & \\
\hline $\mathrm{K}^{+}$ & -0.555 & 0.723 & 0.507 & 0.455 & 0.786 & 1 & & & & & \\
\hline $\mathrm{HCO}_{3}{ }^{-}$ & -0.049 & 0.148 & 0.070 & -0.163 & 0.299 & 0.325 & 1 & & & & \\
\hline $\mathrm{Cl}^{-}$ & -0.635 & 0.934 & 0.866 & 0.900 & 0.814 & 0.549 & -0.049 & 1 & & & \\
\hline $\mathrm{SO}_{4}{ }^{2-}$ & -0.162 & 0.429 & 0.319 & 0.068 & 0.560 & 0.485 & 0.653 & 0.175 & 1 & & \\
\hline $\mathrm{NO}_{3}{ }^{-}$ & -0.764 & 0.878 & 0.743 & 0.662 & 0.913 & 0.723 & 0.317 & 0.767 & 0.503 & 1 & \\
\hline $\mathrm{F}^{-}$ & 0.403 & -0.160 & -0.091 & -0.258 & -0.112 & 0.073 & 0.305 & -0.292 & 0.371 & -0.143 & 1 \\
\hline
\end{tabular}

Bold values indicate good correlation $(r \geq 0.60)$

Table 3 Factor analysis scores (Varimax rotation) of various physicochemical parameters in the study area

\begin{tabular}{lrrrr}
\hline Parameters & Factor I & Factor II & Factor III & Factor IV \\
\hline $\mathrm{pH}$ & -0.725 & 0.191 & 0.511 & 0.223 \\
$\mathrm{EC}$ & $\mathbf{0 . 9 9 1}$ & -0.036 & 0.102 & 0.030 \\
$\mathrm{Ca}^{2+}$ & $\mathbf{0 . 8 9 0}$ & -0.107 & 0.301 & 0.168 \\
$\mathrm{Mg}^{2+}$ & $\mathbf{0 . 8 2 6}$ & -0.377 & 0.300 & 0.072 \\
$\mathrm{Na}^{+}$ & $\mathbf{0 . 9 6 2}$ & 0.147 & -0.044 & 0.001 \\
$\mathrm{~K}^{+}$ & $\mathbf{0 . 7 5 6}$ & 0.306 & -0.134 & -0.446 \\
$\mathrm{HCO}_{3}{ }^{-}$ & 0.199 & $\mathbf{0 . 8 1 7}$ & -0.263 & 0.327 \\
$\mathrm{Cl}^{-}$ & $\mathbf{0 . 9 1 4}$ & -0.294 & 0.144 & 0.074 \\
$\mathrm{SO}_{4}{ }^{2-}$ & 0.452 & $\mathbf{0 . 7 8 1}$ & -0.015 & 0.149 \\
$\mathrm{NO}_{3}{ }^{-}$ & $\mathbf{0 . 9 2 5}$ & 0.126 & -0.191 & -0.027 \\
$\mathrm{~F}^{-}$ & -0.176 & 0.692 & 0.571 & -0.314 \\
Eigen values & 7.426 & 2.167 & 0.935 & 0.518 \\
$\%$ of variance & 61.882 & 18.057 & 7.793 & 4.319 \\
$\mathrm{Cumulative}(\%)^{6}$ & 61.882 & 79.939 & 87.832 & 92.052 \\
\hline
\end{tabular}

The values in bold are factor loadings above 0.65 taken after varimax rotation was performed

reactions influenced by anthropogenic activities. The next Factor II, which explained $18.06 \%$ of the total variance, had strong positive loadings on $\mathrm{HCO}_{3}, \mathrm{SO}_{4}$, and $\mathrm{F}$. The high amount of $\mathrm{SO}_{4}{ }^{2-}$ ion was derived from large amount of chemical fertilizers used in agriculture and industrial effluent in the study area. Factors III and IV were represented with 7.79 and $4.32 \%$ of total variance. The results from Principal component analysis suggested that most of the variations are explained by the set of natural soluble salts and anthropogenic pollutants.

\section{Evaluation of water quality for irrigation use}

Five indices [sodium adsorption ratio (SAR), permeability index (PI), sodium percentage (Na \%), magnesium hazard, and residual sodium carbonate (RSC)] were used to determine the suitability of groundwater for irrigation activities.

\section{Sodium adsorption ratio}

Table 4 shows the calculated values of sodium adsorption ratio (SAR) in the study area. All samples fall under no problem category according to the recommended water classification for SAR (Bouwer 1978). The correlation

Table 4 Irrigational quality parameters results in groundwater samples in the study area

\begin{tabular}{|c|c|c|c|c|}
\hline \multirow[t]{2}{*}{ Parameters } & \multirow[t]{2}{*}{ Range } & \multirow[t]{2}{*}{$\begin{array}{l}\text { Groundwater class } \\
\text { (irrigation uses) }\end{array}$} & \multicolumn{2}{|c|}{$\begin{array}{l}\text { Samples } \\
(n=20)\end{array}$} \\
\hline & & & $\begin{array}{l}\text { In } \\
\text { (no.) }\end{array}$ & \\
\hline \multirow{3}{*}{$\begin{array}{l}\text { SAR (Herman Bouwer } \\
\text { 1978) }\end{array}$} & $<6$ & No problem & 20 & 10 \\
\hline & $6-9$ & $\begin{array}{c}\text { Increasing } \\
\text { problem }\end{array}$ & - & \\
\hline & $>9$ & Severe problem & - & \\
\hline \multirow{2}{*}{$\begin{array}{l}\text { Permeability index (PI) } \\
\text { (Doneen 1964) }\end{array}$} & $<60$ & Suitable & 2 & \\
\hline & $>60$ & Unsuitable & 18 & \\
\hline \multirow[t]{5}{*}{ Na \% (Wilcox 1955) } & $<20$ & Excellent & - & \\
\hline & $20-40$ & Good & - & \\
\hline & $40-60$ & Permissible & 14 & 7 \\
\hline & $60-80$ & Doubtful & 6 & \\
\hline & $>80$ & Unsuitable & - & \\
\hline \multirow{2}{*}{$\begin{array}{l}\text { Magnesium hazard } \\
\text { (Paliwal 1972) }\end{array}$} & $<50$ & Suitable & 8 & \\
\hline & $>50$ & Unsuitable & 12 & \\
\hline \multirow{3}{*}{$\begin{array}{l}\text { Residual sodium carbonate } \\
\text { (after Richards 1954) }\end{array}$} & $<1.25$ & Suitable & 18 & \\
\hline & $1.25-2.5$ & Marginal & 2 & \\
\hline & $>2.5$ & Not suitable & - & \\
\hline
\end{tabular}

In (no.) indicates number of the samples fall in particular category and In (\%) indicates percentage of the samples out of 20 , were fall in the particular category 
between sodium adsorption ratio and electrical conductivity were plotted on the US salinity diagram (Wilcox 1955) and it was found that $80 \%$ of the samples fall in the field of C3-S1 category (Fig. 4). It indicates that these water samples are found in high salinity and low sodium content, which can be used for irrigation in all soil types with low risk of exchangeable sodium. Ten percent of the samples fall in the field of $\mathrm{C} 2-\mathrm{S} 1$ indicating medium salinity and low alkalinity content. This can be suitable for plants having good salt tolerance and it also restricts suitability for irrigation, especially in soils with restricted drainage. Remaining $10 \%$ of the samples fall under C4-S1 category, which indicates very high salinity and low alkalinity content. So, these groundwater samples are suitable for plants having good salt tolerance but unsuitable for irrigation in soils with restricted drainage.

\section{Permeability index}

The permeability Index ranges from 47.7 to $75.8 \%$ with an average value of about $72.14 \%$. The soil permeability is affected by long-term usage of water for irrigation and other purposes. Based on the permeability index in the study area, $90 \%$ of the samples were suitable for irrigation and $10 \%$ of the samples were unsuitable according to the Doneen (1964) water suitability classification for irrigation purpose.

\section{Sodium percentage}

The suitability of the groundwater for irrigation depends on the mineralization of water and its effect on plants and soil. When the concentration of sodium is high in irrigation water, $\mathrm{Na}^{+}$tends to be absorbed by clay particles displacing $\mathrm{Mg}^{2+}$ and $\mathrm{Ca}^{2+}$ ions, thus reducing soil permeability and finally results in soil with poor internal drainage. The calculated values of sodium percentage of the groundwater samples indicate that $70 \%$ of the samples fall in permissible limit except few samples falling under doubtful category according to the Wilcox (1955) water suitability classification for irrigation purpose.

\section{Magnesium hazard (MH)}

Paliwal (1972) introduced a ratio called index of magnesium hazard. Magnesium hazard is expressed as

Magnesium_ratio $=\frac{(\mathrm{Mg})}{(\mathrm{Ca}+\mathrm{Mg})} \times 100$.

The $\mathrm{MH}$ values in the study area ranged from 39.5 to 75.8 and $40 \%$ of the samples were considered suitable for irrigation $(<50 \%)$; meanwhile, $60 \%$ of samples were considered unsuitable for irrigation $(>50 \%)$, indicating their adverse effect on crop yields.

\section{Residual sodium carbonate (RSC)}

Excess amount of magnesium and calcium ions tend to precipitate as carbonate. The sodium concentration increases and gets fixed in the soil thereby decreasing the soil permeability. A high value of RSC in water leads to an increase in the adsorption of sodium in soil (Eaton 1950). The RSC values reveal that the groundwater samples in the monitoring wells are considered suitable for marginal irrigational purpose (Table 4). According to the US
Fig. 4 Salinity and sodium hazard of irrigation water in US salinity diagram

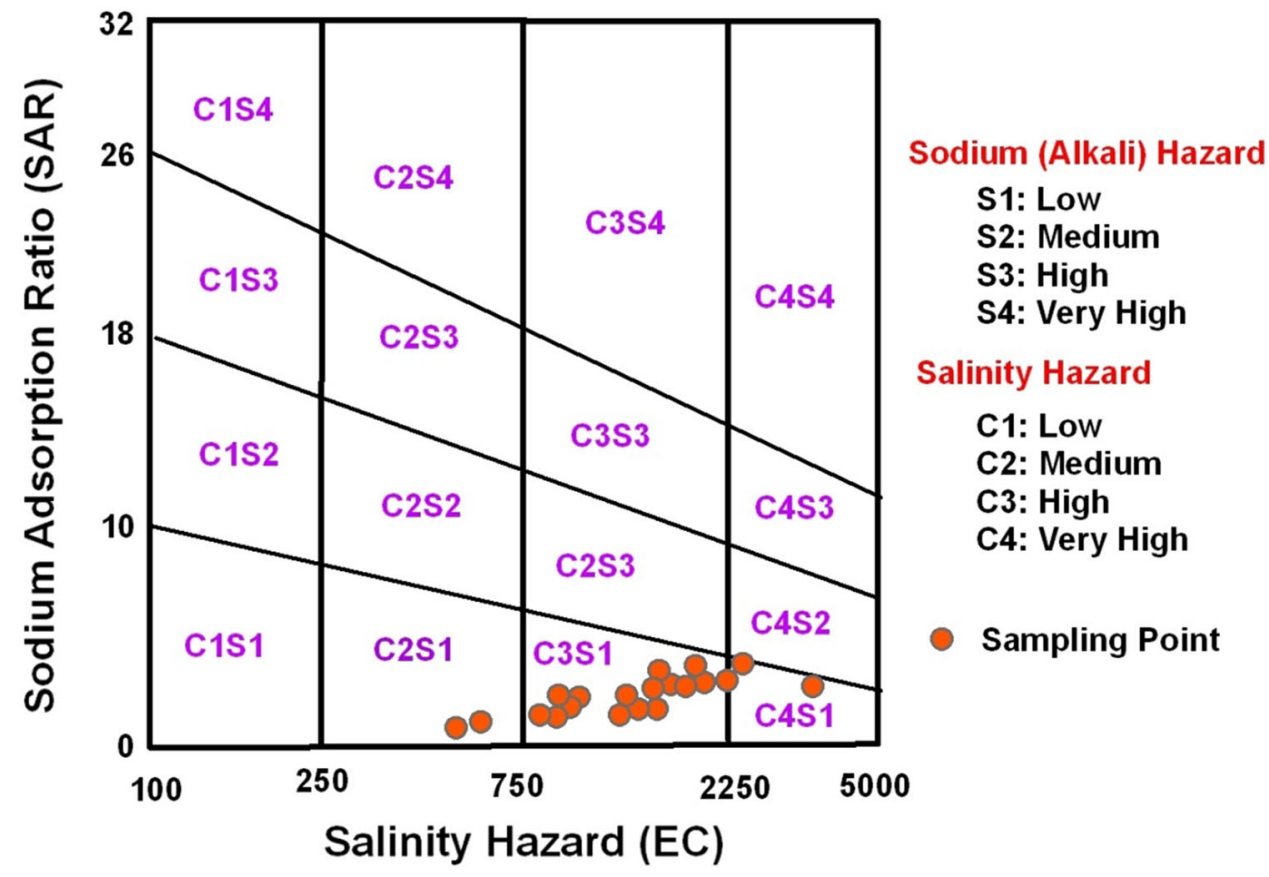


Department of Agriculture, water having $>2.50$ epm of RSC values is not suitable for irrigation purposes. The positive RSC values in 4 samples $(20 \%)$ indicates that dissolved $\mathrm{Ca}^{2+}$ and $\mathrm{Mg}^{2+}$ ions were less than that of $\mathrm{CO}_{3}{ }^{2-}$ and $\mathrm{HCO}_{3}{ }^{-}$contents.

\section{Conclusion}

Based on the analysis of groundwater, it has been possible to understand the geochemical quality of groundwater in the study area and to evaluate its suitability for drinking and irrigation purposes. The study inferred that the groundwater in the study area is slightly alkaline in nature. $\mathrm{Na}, \mathrm{Ca}, \mathrm{HCO}_{3}$, and $\mathrm{Cl}$ are the dominant ions and $45 \%$ of the study area exceeded the recommended limits of TDS. Total hardness reveals that the water is generally hard in nature. The concentrations of major ions in groundwater are within the permissible limits of WHO. The concentration of fluoride is within the permissible limit and is suitable for drinking. The groundwater is dominated by alkaline earths $\left(\mathrm{Ca}^{2+}\right.$ and $\left.\mathrm{Mg}^{2+}\right)$ with weak $\left(\mathrm{HCO}_{3}{ }^{-}\right)$and strong acidic $\left(\mathrm{SO}_{4}{ }^{2-}\right)$ in nature. Based on the Gibb's diagram, evaporation dominance and rockwater interaction dominance are the two main contributors to change the water quality of the study area. The correlation matrix and principal component analysis indicate that the over exploitation of groundwater and anthropogenic inputs are high in the study area. USSL graphical geochemical representation of groundwater quality suggests that majority of the water samples belongs to high and medium salinity with low alkali hazards. The calculated values of SAR, PI, Na \%, and RSC indicate permissible use of groundwater for irrigation purposes. Comparison of geochemical data shows that majority of the groundwater samples are suitable for drinking and irrigation purposes.

Open Access This article is distributed under the terms of the Creative Commons Attribution License which permits any use, distribution, and reproduction in any medium, provided the original author(s) and the source are credited.

\section{References}

Andrade E, Palacio HAQ, Souza IH, Leao RA, Guerreio MJ (2008) Land use effects in groundwater composition of an alluvial aquifer by multivariate techniques. Environ Res 106:170-177

APHA (1995) standard methods for the examination of water and wastewater, 19th edn. APHA, Washington, DC

BIS (1991) Bureau of Indian Standards, IS:10500. Manak Bhawan, New Delhi

Bouwer H (1978) Groundwater hydrology, International student edition. McGraw-Hill Kogakusha, Ltd., Tokyo, pp 480
Brindha K, Elango L (2012) Groundwater quality zonation in a shallow weathered rock aquifer using GIS. J Geo Spat inf Sci: $1-10$

Carneiro PA, Umbuzeiro GA, Oliveira DP, Zanoni MV (2010) Assessment of water contamination caused by a mutagenic textile effluent/dyehouse effluent bearing disperse dyes. J Hazard Mater 174(1-3):694-699

Central Ground Water Board (CGWB) (2008) District groundwater brochure, Tiruchirappalli district, Tamil Nadu, Technical report series, pp 5-7

Chandrasekar N, Selvakumar S, Srinivas Y, John Wilson JS, Simon Peter T,Magesh NS (2013). Hydrogeochemical assessment of groundwater quality along the coastal aquifers of southern Tamil Nadu, India. Environ Earth Sci. doi:10.1007/s12665-013-2864-3

Doneen LD (1964) Notes on water quality in agriculture. In: Published in water science and engineering. University of California, Davis

Eaton FM (1950) Significance of carbonates in irrigation waters. Soil Sci 39:123-134

Edmunds WM, Shand P, Hart P, Ward RS (2003) The natural (baseline) quality of groundwater: a UK pilot study. Sci Total Environ 310:25-35

Elkrail AB, Obied BA (2012) Hydrochemical characterization and groundwater quality in Delta Tokar alluvial plain, Red Sea coastSudan. Arab J Geosci. doi:10.1007/s 12517-012-0594-6

Freeze AR, Cherry JA (1979) Groundwater. Prentice-Hall, NJ

Gordana D, Dragana D, Sanja S (2014) Natural and anthropogenic factors affecting the groundwater quality in Serbia. Sci Total Environ:933-942

Hem JD (1989) Study and interpretation of chemical characteristics of natural waters, $3 r d$ edn. US geological survey water supply paper 2254

ISI (1983) Drinking water standard-substances or characteristic affecting the acceptability of water for domestic use. ISI0500, pp1-22

Jameel A, Padusha MSA, Zaheer Hussain A (2004) Studies on ground water pollution of tannery effluent at Sempattu, Tiruchirappalli, Tamilnadu. Intern Conf (JARJ) 1(2):7-9

Jankowski J, Acworth RI (1997) Impact of depris-flow deposits on hydrogeochemical processes and the development of dry land salinity in the Yass River catchment, New South Wales. Aust Hydro geol J 5(4):71-88

Muthukumar S, Lakshmanan C, Sathya G, Krishnakumar P, Viveganandam S (2011) Assessment of water quality in Trichy city, Tamil Nadu, India. Int J Environ Sci 1(7)

Olajire AA, Imeokparia FE (2001) Water quality assessment of Osun River: studies on inorganic nutrients. Environ Monit Assess 69(1):17-28

Paliwal KV (1972) Irrigation with saline water. In: Monogram no. 2 (new series). IARI, New Delhi, pp 198

Piper AM (1944) A graphic procedure in geochemical interpretation of water analysis. Trans Am Geophys Union 25(6):914-928

Raju KCB (1998) Importance of recharging depleted aquifers: state of the art of artificial recharge in India. J Geol Soc India 5:429-454

Richards LA (US Salinity laboratory) (1954) Diagnosis and improvement of saline and alkaline soils. In: US Department of Agriculture Hand Book. pp 60

Selvakumar S, Chandrasekar N, Srinivas Y, Simon peter T, Magesh NS (2014) Evaluation of the groundwater quality along coastal stretch between Vembar and Taruvaikulam, Tamil Nadu, India; a statistical approach. J Coast Sci 1:22-26

Shuxian W (2013) Groundwater quality and its suitability for drinking and agricultural use in the Yanqi Basin of Xinjiang Province, Northwest China. Environ Monit Assess. doi:10.1007/s 10661-013-3113-7 
Subba Rao N (2014) Spatial control of groundwater contamination, using principal component analysis. J Earth Syst Sci 123(4):715-728

USSL (1954) Diagnosis and improvement of salinity and alkaline soil. In: USDA Hand Book No. 60. Washington

Walton WC (1970) Groundwater resources evaluation. McGraw Hill Book Co, New York

Whittemore DO, Greggor KMM, Marotz GA (1989) Effects of variations in recharge on groundwater quality. J Hydrol 106:131-145
WHO (2004) Guidelines for drinking water quality, 3rd edn. World Health Organization, Geneva

Wilcox LV (1955) Classification and use of irrigation waters, USDA Circular No. 969. pp 19

Zhang B, Song X, Zhang Y, Han D, Tang C, Yu Y (2012) Hydrogeochemical characteristics and water quality assessment of surface water and groundwater in Songnen plain, Northeast china. Water Res 46(8):2737-2747 